\title{
Radiation hazard in soil from Ajaokuta North-central Nigeria
}

\author{
M.R. Usikalu. ${ }^{1 *}$, A.B. Rabiu ${ }^{2}$, K.D. Oyeyemi ${ }^{1}$, J.A. Achuka1, \\ M. Maaza ${ }^{3}$
}

\author{
${ }^{1}$ Department of Physics, Covenant University, P.M.B 1023, Otta, Ogun State, Nigeria \\ ${ }^{2}$ Centre for Atmospheric Research, NASRDA, Kogi State University, Ayimgba, Nigeria \\ ${ }^{3}$ Material Science Department, iThemba Labs, Somerset West, South Africa
}

\section{- Short report}

\section{${ }^{*}$ Corresponding author:}

Dr. Usikalu Mojisola,

\section{E-mail:}

moji.usikalu@covenantuniversity.edu.ng

Revised: May 2016

Accepted: July 2016

Int. J. Radiat. Res., April 2017; 15(2): 219-224

DOI: 10.18869 /acadpub.ijrr.15.2.219

\begin{abstract}
Background: Measurement of the radiation dose distribution is important in assessing the health risk a population and serve as reference in documenting changes to environmental radioactivity in soil due to man-made activities. Materials and Methods: The activity concentration of ${ }^{238} \mathrm{U},{ }^{232} \mathrm{Th}$ and ${ }^{40} \mathrm{~K}$ in soil samples obtained from different locations in Ajaokuta Local Government area was measured using Hyper Pure germanium Detection System (HPGe). Results: The calculated average concentration of the radionuclides ranged from $12 \pm 1 \mathrm{Bqkg}^{-1}$ to $59 \pm 2 \mathrm{Bqkg}^{-1}$ for ${ }^{238} \mathrm{U}, 14 \pm 1 \mathrm{Bqkg}^{-1}$ to $78 \pm 5 \mathrm{Bqkg}^{-1}$ for ${ }^{232} \mathrm{Th}$ and $49 \pm 2 \mathrm{Bqkg}^{-1}$ to $1272 \pm 23 \mathrm{Bqkg}^{-1}$ for ${ }^{40} \mathrm{~K}$. In order to evaluate the radiological hazards due to natural radionuclides within Ajaokuta, the absorbed dose rate, gamma index, radium equivalent and excess lifetime cancer risk were estimated. According to measured data from the top soil $(0-10 \mathrm{~cm})$, the estimated radium equivalent $\left(\mathrm{Ra}_{\mathrm{eq}}\right)$ ranges from $55.7 \mathrm{Bqkg}^{-1}$ at Steel Complex to $253.3 \mathrm{Bqkg}^{-1}$ obtained from Forest samples. Conclusion: The mean absorbed dose rate, annual effective dose and gamma radiation index evaluated were $66.2 \mathrm{nGyh}^{-1}, 81.2 \mu \mathrm{Svy}^{-1}$ and 1.05 respectively which are higher than the recommended limit for normal background radiation. Thus, we conclude that people living in these locations may be exposed to higher radiation.
\end{abstract}

Keywords: Radiation hazard, gamma index, excess lifetime cancer risk, soil, Ajaokuta.

\section{INTRODUCTION}

Natural radioactivity includes the primordial and cosmogenic radionuclides that are common in rocks, soils, water and oceans that make up our planet (1). It is found also in our building materials constituting main sources of radiation exposure for human beings. Radionuclides are inhaled and ingested every day through breathing and food chain $(2,3)$. According to the ALARA principle, "limits" are established by International commissions, but we know well that (especially) stochastic effects have no a threshold. In order to reduce them "as low as (is) reasonably achievable", we must limit exposure to radiation sources. It is therefore pertinent to design mechanisms to monitor the levels of these radionuclides due to their harmful effects $(4,5)$. Gamma dose measurements have been conducted in different areas of Nigeria through soil radionuclides. This is the first systematic and extensive study of this kind in the study area. This paper deals with the measurement of decay products of uranium/ thorium series and primordial radionuclide ${ }^{40} \mathrm{~K}$ in soil samples taken from various parts of Ajaokuta. Within the framework of this research, radiological parameters that include absorbed dose rate, annual effective dose, gamma index and excess life cancer risk have been estimated 
from the activity concentration of ${ }^{238} \mathrm{U},{ }^{232} \mathrm{Th}$ and ${ }^{40} \mathrm{~K}$. The aim of this study is to assess the health risks associated to the presence of these radionuclides and develops a baseline of natural background radiation levels for the area.

\section{Study area}

The area of study is Ajaokuta Local Government area in Kogi state, Nigeria (figure 1). Ajaokuta is located $07^{\circ} 53^{\prime} 94^{\prime \prime} \mathrm{N}$ and $006^{\circ}$ $64^{\prime} 24^{\prime \prime} \mathrm{E}$ to the left bank of the Niger River; situated within the crystalline basement complex (6). It is a $1,362 \mathrm{~km}^{2}$ wide and has a population of 122,321 at the 2006 census, with mean temperature of $26^{\circ} \mathrm{C}$ and relative humidity of $88 \%$ (6). The crystalline complex rocks (figure 1) are predominantly gneiss, migmatite and older meta-sediment rocks comprising quartzite, marble calc-silicate and the pan Africa granites/ older granites. The geology of the area reveals that rocks are from Pre-cambium crystalline basement complex and the Cretaceous (Campbanian-Maastrichian) sedimentary of the Mid-Niger Basin.

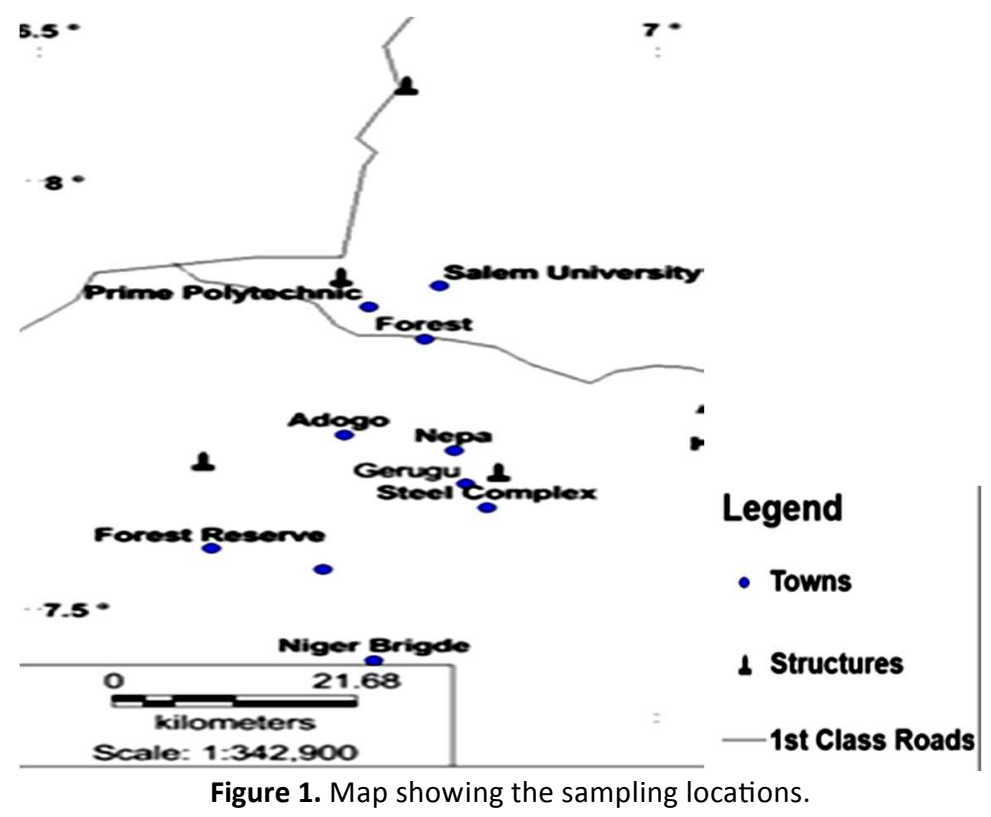

\section{MATERIALS AND METHODS}

\section{Sample preparation and measurements}

The samples were collected by digging the ground to at least $3 \mathrm{~cm}$ then taken the soil from there. Five soil samples were taken from different points at each location making a total of fifty samples collected using composite sampling method for better sampling. The samples were then kept in Ziplock bags and labelled accordingly. The samples were dried at $110^{\circ} \mathrm{C}$ in an oven to ensure complete removal of moisture until constant weight was attained. Dried samples were grinded and passed through a $2 \mathrm{~mm}$ sieve. $100 \mathrm{~g}$ of each sample were placed in a radon-tight plastic vessel, $9 \mathrm{~cm}$ in diameter Int. J. Radiat. Res., Vol. 15 No. 2, April 2017 with a total capacity of $300 \mathrm{~cm}^{3}$. The vessels were weighted and sealed for 30 days to allow equilibrium in the ${ }^{238} \mathrm{U}$ and ${ }^{232} \mathrm{Th}$ with their respective progeny ${ }^{(7)}$.

Gamma ray spectrometric method was used for the radioactivity measurement (model GC8023). The detector was coupled with multi-channel analyser (MCA) through pre amplifier base. The detector is properly shielded with lead to prevent external radiation from environment. An International Atomic Energy Agency (IAEA) standard reference soil sample (MGS6M315) with specific activity was engaged in calibrating the detector. The peak $1.46 \mathrm{MeV}$ was employed for ${ }^{40} \mathrm{~K}$; $2.61 \mathrm{MeV}$ ( ${ }^{208} \mathrm{Ti}$ ) for ${ }^{232} \mathrm{Th}$ and $1.76 \mathrm{MeV}\left({ }^{214} \mathrm{Bi}\right)$ for ${ }^{238} \mathrm{U}$ respectively were 
used to estimate radionuclide contents of the samples using the Genie 2000 software $(8,9)$. Each sample was counted for 36,000 seconds to improve statistics. The specific activity was calculated using equation 2 and the activity concentrations of ${ }^{238} \mathrm{U},{ }^{232} \mathrm{Th}$, and ${ }^{40} \mathrm{~K}$ were estimated using Equation 3. The measured parameters were analysed using Excel spreadsheet and Surfer 11 software

$$
\text { Specific activity }\left(\mathrm{Bq} \mathrm{kg}^{-1}\right)=\frac{\text { Net Area }-\mathrm{B} . \mathrm{G}}{t \varepsilon P_{\gamma} M}
$$

Net Area $=$ Net area under energy peak (count).

B.G = the number of counts for the background spectrum.

$\mathrm{t}=$ the counting time

$\mathrm{P}_{\gamma}=$ the gamma emission probability at energy $E$

$\varepsilon=$ the absolute efficiency of the detector, and $\mathrm{M}=$ the weight of the dried sample $(\mathrm{kg})$.

$$
\operatorname{Activity}(B q)=\frac{C P S \times 100 \times 100}{B . I \times E_{f f}} \pm \frac{C P S_{e r r o r} \times 100 \times 100}{B . I \times E_{f f}}
$$

Where; CPS is the net count rate per second, B.I is the branching intensity and Eff is the efficiency of the detector.

\section{RESULTS AND DISCUSSION}

Table 1 presents the mean concentration of the radionuclides, as well as the corresponding statistical error for five samples each under investigations at the ten locations within the study area. The activity concentrations of $238 \mathrm{U}$, ${ }^{232} \mathrm{Th}$, and ${ }^{40} \mathrm{~K}$ are found to vary from $12 \pm 1$ Bqkg-1 to $59 \pm 2 \mathrm{Bqkg}^{-1}, 14 \pm 1 \mathrm{Bqkg}^{-1}$ to $77 \pm 5$ Bqkg- $^{-1}$ and $49 \pm 2$ Bqkg$^{-1}$ to $1272 \pm 23$ Bqkg$^{-1}$ respectively in the soil samples studied in this research. The highest level of ${ }^{238} \mathrm{U}\left(59 \mathrm{Bqkg}^{-1}\right)$ and ${ }^{40} \mathrm{~K}\left(1272 \mathrm{Bqkg}^{-1}\right)$ are obtained from the soils from Salem University. The highest level of ${ }^{232} \mathrm{Th}$ (78 $\left.\mathrm{Bqkg}^{-1}\right)$ was obtained from soil samples collected from Forest. The measured concentration of ${ }^{40} \mathrm{~K}$ is found to be higher than that of ${ }^{232} \mathrm{Th}$ and ${ }^{238} \mathrm{U}$ in all the locations studied. It varied from below detection limit (BDL) and $1272 \mathrm{~Bq} \mathrm{~kg}^{-1}$ having a mean value of $712 \mathrm{~Bq}$ 221 $\mathrm{kg}^{-1}$. High activity concentration level of ${ }^{40} \mathrm{~K}$ in this location may be probably due to application of inorganic phosphate rich fertilizer used for agricultural activities.

World average concentrations are $33 \mathrm{Bqkg}$ ${ }^{1}$ and $45 \mathrm{Bqkg}^{-1}$ for ${ }^{238 \mathrm{U}}$ and ${ }^{232} \mathrm{Th}$ respectively; and typical ranges are $16-36 \mathrm{Bqkg}^{-1}$ for ${ }^{238} \mathrm{U}$ and 7 - $50 \mathrm{Bqkg}^{-1}$ for ${ }^{232} \mathrm{Th}$. Similarly, the world average concentration for ${ }^{40} \mathrm{~K}$ is $420 \mathrm{Bqkg}^{-1}$, and typical range is $100-700 \mathrm{Bqkg}^{-1}$ for ${ }^{40} \mathrm{~K}(10)$. It is evident from Table 1 that the concentration of Uranium $(238 \mathrm{U})$ is higher than the world standard at Salem University, Forest, Nepa, and Niger Bridge; whereas, the activity concentration of Thorium ( ${ }^{232} \mathrm{Th}$ ) is greater than that of the world standard obtained at Salem University and Forest. The natural radionuclides measured in this study is comparable with that obtained in other countries such as, Jordan (49, 27, 291 Bqkg-1$^{-1}$ ), Turkey (37, 40, $667 \mathrm{Bqkg}^{-1}$ ) and Yemen $\left(44,58,823 \mathrm{Bqkg}^{-1}\right)$ for ${ }^{238} \mathrm{U},{ }^{232} \mathrm{Th}^{-1}$ and ${ }^{40} \mathrm{~K}$ concertation respectively $(11,12,13)$. The elevated concentrations of $238 \mathrm{U}$ and ${ }^{232} \mathrm{Th}$ measured in these locations may be attributed to the geology and geographical conditions of these locations, from the geology point of view these locations belong to basement complex which is associated with igneous rock. This corroborates the report by ${ }^{(10)}$ and (14) that igneous rocks such as granite are associated with a higher level of radiation when compared with sedimentary rock.

\section{Estimation of radiological parameters}

Radium equivalent activity is calculated in order to compare the activity concentration of samples containing varying amounts of $238 \mathrm{U}$, ${ }^{232} \mathrm{Th}$, and ${ }^{40} \mathrm{~K}$ with respect to radiation exposure. It is estimated using Equation 4 (15):

$$
R a_{e q}=C_{U}+1.43 \times C_{T h}+0.077 \times C_{K}
$$

Where $\mathrm{C}_{\mathrm{U}}, \mathrm{C}_{\mathrm{Th}}$ and $\mathrm{C}_{\mathrm{K}}$ are the concentrations $\left(\mathrm{Bqkg}^{-1}\right)$ of ${ }^{238} \mathrm{U},{ }^{232} \mathrm{Th}$, and ${ }^{40} \mathrm{~K}$, respectively in the soil samples. The range of the radium equivalent activity within the study area varies from 55.74 $\mathrm{Bqkg}^{-1}$ at Steel Complex to 253.27 Bqkg-1 at Forest.

In order to estimate the absorbed and

Int. J. Radiat. Res., Vol. 15 No. 2, April 2017 
effective dose according to (10), the measured activity of ${ }^{238} \mathrm{U},{ }^{232} \mathrm{Th}$, and ${ }^{40} \mathrm{~K}$ were converted into dose (nGyh-1) by applying the dose factors $0.462,0.604$, and 0.0417 for uranium, thorium and potassium respectively (16). The factors were applied to calculate the total absorbed gamma dose rate in air at $1 \mathrm{~m}$ above the ground level using equation 5.

Table 1. Activity concentration measured in Ajaokuta LGA

\begin{tabular}{|c|c|c|c|c|}
\hline Location & $\mathbf{N o}$ & ${ }^{\mathbf{2 3 8}} \mathbf{U}\left(\mathbf{B q ~ k g}^{-\mathbf{1}}\right)$ & ${ }^{\mathbf{2 3 2}} \mathbf{T h} \mathbf{( B q ~ \mathbf { ~ g } ^ { - 1 } )}$ & ${ }^{{ }^{\mathbf{1 0}}} \mathbf{K}\left(\mathbf{B q ~ k g}^{-\mathbf{1}}\right)$ \\
\hline Salem University & 5 & $59 \pm 2$ & $63 \pm 5$ & $1272 \pm 23$ \\
\hline Prime Polythecnic & 5 & $15 \pm 1$ & $27 \pm 2$ & $701 \pm 14$ \\
\hline Forest & 5 & $46 \pm 3$ & $78 \pm 5$ & $1242 \pm 23$ \\
\hline Steel Complex & 5 & $30 \pm 1$ & $15 \pm 1$ & $49 \pm 2$ \\
\hline Ajaokuta & 5 & $12 \pm 1$ & $14 \pm 1$ & $553 \pm 11$ \\
\hline Nepa & 5 & $44 \pm 3$ & $33 \pm 3$ & $1090 \pm 20$ \\
\hline Adogo & 5 & $23 \pm 1$ & $17 \pm 1$ & $870 \pm 16$ \\
\hline Forest Reserve & 5 & $21 \pm 1$ & $37 \pm 3$ & $\mathrm{BDL}$ \\
\hline Gerugu & 5 & $26 \pm 2$ & $35 \pm 3$ & $649 \pm 13$ \\
\hline Niger Bridge & 5 & $34 \pm 3$ & $42 \pm 3$ & $692 \pm 13$ \\
\hline Minimum & & $12 \pm 1$ & $14 \pm 1$ & $49 \pm 2$ \\
\hline Maximum & & $59 \pm 2$ & $78 \pm 5$ & $1242 \pm 23$ \\
\hline Mean \pm SD & & $31 \pm 2$ & $36 \pm 3$ & $712 \pm 13$ \\
\hline
\end{tabular}

Absorbed dose (D) $\left(\mathrm{nGyh}^{-1}\right)=$ $0.462 \mathrm{C}_{\mathrm{U}}+0.604 \mathrm{C}_{\mathrm{Tn}}+0.0417 \mathrm{C}_{\mathrm{K}}$

where $\mathrm{C}_{\mathrm{U}}, \mathrm{C}_{\mathrm{Th}}$ and $\mathrm{C}_{\mathrm{K}}$ are the activity $\left(\mathrm{Bq} \mathrm{kg}^{-1}\right)$ of uranium, thorium and potassium in the soil samples. The annual effective doses were estimated putting into consideration the conversion coefficient from the absorbed dose in the air to effective dose, this involves using the conversion factor of $0.7 S v G y^{-1}$ to convert the absorbed rate to annual effective dose with and outdoor occupancy of $20 \%$. This is calculated using the Equation 6.

Outdoor annual effective dose $=($ Absorbed dose) nGyh $^{-1} \times 8760 \mathrm{~h} \times 0.2 \times 0.7 \mathrm{SvGy}^{-1}$

The absorbed dose rate and annual effective dose rate from the soil samples were calculated and presented on table 2 . It showed that the minimum and maximum annual dose was obtained in steel complex and Forest respectively.

Calculation of external indices includes that of gamma index ( $\mathrm{I}_{\Upsilon}$ ) for a typical material, according to (17), the gamma index determined as given by equation 7 .

$$
I_{y}=\sum_{x} \frac{C_{x}}{A_{x}}
$$

Where $\mathrm{C}_{\mathrm{x}}\left(\mathrm{Bq} \mathrm{kg}{ }^{-1}\right)$ is the measured activity of each nuclide in the building material, $A_{x}(B q$ $\mathrm{kg}^{-1}$ ) is the activity concentration of each nuclide in the material and it is assumed to produce the same gamma dose rate, i.e. 300,200 , and 3000 $\mathrm{Bqkg}^{-1}$ for ${ }^{238 \mathrm{U}},{ }^{232} \mathrm{Th}$, and ${ }^{40} \mathrm{~K}$ respectively. Based on the dose criterion of $1 \mathrm{mSvy}^{-1}$ for public exposure, the estimated gamma index ( $I_{Y}$ ) for soil samples is presented in table 2 . Figure 2 is the image map of gamma index. It is obvious that Ir is greater than unity in soil samples from Salem University, Forest, Nepa and Niger Bridge within the study area. The soil samples with values greater than unity failed to satisfy the safety criterion from radiation point of view hence, these soils within the areas may not be good for building and construction purposes.

The excess lifetime cancer risk $\left(E_{\mathrm{L}}\right)$ and percentage risk were estimated in order to obtain the probability of developing cancer over a lifetime at a given exposure level using (18) equation. Figure 3 is the correlation of the excess lifetime cancer risk and annual effective dose rate with a trend line was drawn between 
the points using regression analysis technique. The correlation between the excess lifetime cancer risk and annual effective dose rate was very high (1). The high correlation obtained may be due to the retaining capability of the soil of these radionuclides under different atmospheric conditions. The estimated average excess lifetime cancer risk ranged between $0.16 \times 10^{-3}$ and $0.52 \times 10^{-3} \quad \mu S_{v y}^{-1}$ with percentage risk between $-62.67 \%$ and $78.48 \%$. Although the mean excess lifetime cancer estimated for all the locations is $0.28 \times 10^{-3} \mu \mathrm{Svy}^{-1}$, which is slightly less than the standard $0.29 \times 10^{-3} \mu \mathrm{Svy}^{-1}$, the soils from Salem University, Forest, Nepa and Niger Bridge remain above this limit. Therefore, people living or working in these areas may be exposed to high radiation from natural radionuclides.

Table 2. Estimated Radiological Parameters for Ajaokuta LGA.

\begin{tabular}{|c|c|c|c|c|c|}
\hline Location & $\mathrm{D}\left(n G y h^{-1}\right)$ & $H_{E}\left(\mu S v y^{-1}\right)$ & $I_{v}$ & $\mathrm{E}_{\mathrm{L}}\left(\mu S v y^{-1}\right)$ & \%Risk \\
\hline Salem University & 119.13 & 146.1 & 1.88 & 0.511 & 76.33 \\
\hline Prime Polytechnic & 52.58 & 64.48 & 0.84 & 0.226 & -22.18 \\
\hline Forest & 120.58 & 147.88 & 1.91 & 0.518 & 78.48 \\
\hline Steel Complex & 25.22 & 30.98 & 0.39 & 0.108 & -62.67 \\
\hline Ajaokuta & 37.34 & 45.79 & 0.59 & 0.16 & -44.74 \\
\hline Nepa & 86.19 & 105.7 & 1.35 & 0.37 & 25.57 \\
\hline Adogo & 57.65 & 70.7 & 0.91 & 0.247 & -14.67 \\
\hline Forest Reserve & 32.35 & 39.67 & 0.51 & 0.139 & -52.12 \\
\hline Gerugu & 60.61 & 74.33 & 0.96 & 0.26 & -10.29 \\
\hline Niger Bridge & 70.24 & 86.14 & 1.11 & 0.301 & 3.96 \\
\hline Mean & 66.19 & 81.18 & 1.05 & 0.28 & -2.23 \\
\hline
\end{tabular}

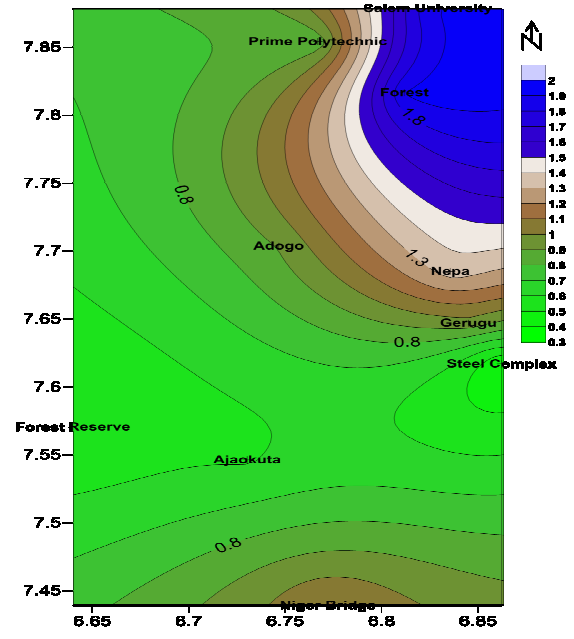

Figure 2. Map showing estimated Gamma Index within the study area.

\section{CONCLUSION}

The estimated activity concentration for ${ }^{238} \mathrm{U}$, ${ }^{232} \mathrm{Th}$, and ${ }^{40} \mathrm{~K}$ in soils samples from different sampling locations in Ajaokuta Local Government of Kogi State, Nigeria is found to 223

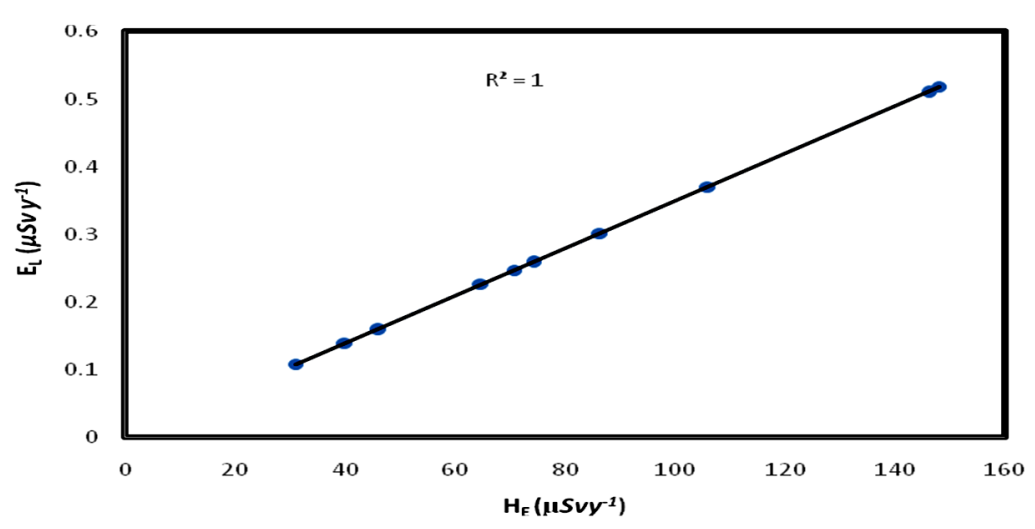

Figure 3. Correlation of excess lifetime cancer risk and annual effective dose rate.

vary from one location to another. The highest level of ${ }^{238} \mathrm{U}$ and ${ }^{40} \mathrm{~K}$ are observed within Salem University. The highest level of ${ }^{232} \mathrm{Th}$ was detected from soil samples obtained from Forest. Radiological parameters estimated were found to be relatively higher in Salem University, Forest, Nepa and Niger Bridge. The soils from these areas may put the users of the soils and people around these areas on a radiological hazard.

Int. J. Radiat. Res., Vol. 15 No. 2, April 2017 


\section{ACKNOWLEDGEMENTS}

The Centre for Atmospheric Research, CAR, National Space Research and Development Agency, funded this research under the Atmospheric Chemistry and Environmental Research Project. The first author acknowledged International Centre of Theoretical Physics for support in term of literatures provided for the study.

\section{Conflicts of interest: Declared none.}

\section{REFERENCES}

1. Tso MY and Leung JK (2000) Population dose due to natural radiations in Hong Kong. Health Physics, 8:555-578.

2. Chikasawa K, shii TI, Ugiyama H (2001) Terrestrial gamma radiation in Kochi Prefecture, Japan. J Health Sci, 47: 361 372.

3. Dhawal SJ, Kulkarni GS, Pawar SH (2013) Terrestrial background radiation studies in South Konkan, Maharashtra, India. Int J Radiat Res, 11(4): 263-270.

4. Usikalu MR, Maleka PP, Malik M, Oyeyemi KD, Adewoyin OO (2015) Assessment of geogenic natural radionuclide contents of soil samples collected from Ogun State, South western, Nigeria. Int J Radiat Res, 13(4): 355-361.

5. Kant K, Gupta R, Kumari, Gupta N, Garg M (2015) Natural radioactivity in Indian vegetation samples. Int J Radiat Res, 13(2): 143-150.

6. Abimbola AF, Ojo AM, Okunlola OA, Oguntoyinbo FI (2002) Agrogeological studies of limestone, phosphate and gypsumoccurrences in the Dahomey Basin, Southwestern $\mathrm{Ni}$ geria in relationto Soil Acidity Amelioration. Nig J Sci, 36: 119-128.

7. Myrick TE, Berven BA, Haywood FF (1983) Determination of concentrations of selected radionuclides in surface soil in the U.S. Health Phys, 45: 631-642.

8. Lalit BY and Ramachandran TV (1980) Natural radioactivity in Indian food stuffs. Natural Radiation Environment III, Proceedings of an International Symposium held at Houston, Texas, USA, CONF - 7804222, 800-809.

9. Mishra UC, Lalit BY, Shukla VK, Ramachandran TV (1981) Standardized low level measurement methods for environmental studies. STI/PUB/529. Vienna: IAEA, 189-191.

10. UNSCEAR (2000) Sources and effects of ionizing radiations, report to the General Assembly with Scientific Annexes, United Nations, New York, USA.

11. Al-Hamarneh, IF and Awadallah, MI (2009) Soil radioactivity levels and radiation hazard assessment in the highlands of Northern Jordan. Radiation Measurements, 44: 102-110.

12. Zarie KA and Al Mugren KS (2010) Measurement of natural radioactivity and assessment of radiation hazard in soil samples from Tammy area (KSA). Isotope and Radiation Research, 42: 1-9.

13. Abd El-mageed Al, El-Kamel AH, Abbady A, Harb S, Youssef AMM, Saleh II (2011) Assessment of natural and anthropogenic radioactivity levels in rocks and soils in the environments of Juban Town in Yemen, Radiation Physics and Chemistry, 80: 710-715.

14. Sahu SK, Ajmal PY, Bhangare RC, Tiware M, Pandit GG (2014) Natural radioactivity assessment of a phosphate fertilizer plant area. Journal of Radiation and Applied Sciences, 1(1): 123-128.

15. Beretka J, and Mathew PJ (1985) Natural radioactivity of Australian building materials, building materials, Health Phys, 45: 349-361.

16. UNSCEAR (1993) Exposure from natural sources of radiation, report to the General Assembly with Scientific Annexes, United Nations, New York, USA.

17. European Commission (EC) (1999) Radiation Unit, Radiological protection principles.

18. Taskin H, Karavus M, Ayb P, Topuzoglu, A, Hidiroglu S, Karahan $G$ (2009) Radionuclide concentrations in soil and lifetime cancer risk due to gamma radioactivity in Kirklareli, Turkey. Journal of Environmental Radioactivity, 100: 49-53. 